\title{
The VZV/IE63-specific T cell response prevents herpes zoster in fingolimod-treated patients OPEN
}

Amandine Mathias, $\mathrm{PhD}$ Guillaume Perriard, PhD Mathieu Canales Fanny Vuilleumier, BS Gaetano Perrotta, MD Myriam Schluep, MD Renaud Du Pasquier, MD

Correspondence to Dr. Du Pasquier: Renaud.Du-Pasquier@chuv.ch

Supplemental data at Neurology.org/nn

\section{ABSTRACT}

Objective: To assess longitudinally the antiviral immune response of $T$ cells from patients with multiple sclerosis (MS) treated with fingolimod (FTY) vs other disease-modifying treatments (DMTs).

Methods: We assessed cellular immune responses specific to influenza virus (FLU), JC virus (JCV), and varicella-zoster virus (VZV) using quantification of interferon- $\gamma$ secretion by enzyme-linked immunospot in patients with MS on FTY $(n=31)$, including 2 with herpes zoster $(H Z)$, natalizumab $(n=11)$, and other DMTs $(n=11)$. We used viral lysates for FLU and $V Z V$ and a pool of peptides for FLU, JCV (VP-1), and VZV (IE63).

Results: Besides an expected drop of T cells, we found that, proportionally to the number of $\mathrm{CD}^{+}$ $\mathrm{T}$ cells, only FTY-treated patients with MS exhibited an increased VZV/IE63-specific T cell response peaking 6 months into treatment, a response that returned to baseline after 12 and 24 months. Two FTY-treated patients developed an HZ 6 months into treatment, coinciding with an absent $V Z V / I E 63-s p e c i f i c ~ T$ cell response. However, cellular immune responses specific to VZV lysate, JCV, and FLU (lysate and pool of peptide epitopes) were similar between all 3 categories (FTY, natalizumab, and other DMTs) of study patients.

Conclusions: FTY-treated patients with MS exhibit an increased VZV/IE63-specific cellular immune response after 6 months of treatment. FTY-treated patients who develop an $\mathrm{HZ}$ are not able to mount such a response, suggesting that a $T$ cell response directed against this viral protein may be key in preventing the occurrence of HZ. Neurol Neuroimmunol Neuroinflamm 2016;3:e209; doi: 10.1212/NXI.0000000000000209

\section{GLOSSARY}

DMT = disease-modifying treatment; ELISPOT = enzyme-linked immunospot; FLU = influenza virus; FTY = fingolimod; $\mathbf{H Z}=$ herpes zoster; IFN- $\boldsymbol{\gamma}=$ interferon- $\boldsymbol{\gamma}$; JCV $=$ JC virus; $\mathbf{M S}=$ multiple sclerosis; $\mathbf{N T Z}=$ natalizumab; PBMC $=$ peripheral blood mononuclear cell; $\mathbf{S F C}=$ spot-forming cell; $\mathbf{V Z V}=$ varicella-zoster virus.

Fingolimod (FTY), a treatment of relapsing-remitting multiple sclerosis (MS), is thought to be active by specifically trapping naive and central memory $T$ cells within the lymph nodes, with, as a consequence, a lymphopenia. ${ }^{1}$ There are scarce reports of a putative association of FTY with cryptococcal meningitis, ${ }^{2}$ herpes simplex virus 1 infection, ${ }^{3,4}$ and progressive multifocal leukoencephalopathy ${ }^{5}$; however, the overall incidence is clearly very low. Thus, the reported overall incidence of infections does not seem to be significantly higher in patients receiving FTY as compared to control study participants. By contrast, the occurrence of varicella-zoster virus (VZV) is significantly increased in FTY-treated patients. ${ }^{6,7}$ Authors have reported a reduction in the frequency of interferon- $\gamma$ (IFN- $\gamma$ )-secreting VZV-specific T cells in FTY-treated patients 3 months after treatment initiation, but this difference disappeared when the $\mathrm{CD} 3^{+} \mathrm{T}$ cell count was normalized. ${ }^{8}$ Thus, the question of whether there is a dysregulated VZV-specific $\mathrm{T}$ cell response in FTY-treated patients with MS remains open. Furthermore, it is unknown whether

From the Laboratory of Neuroimmunology, Center of Research in Neurosciences (A.M., G. Perriard, M.C., F.V., R.D.P.), and Service of Neurology (G. Perrotta, M.S., R.D.P.), Department of Clinical Neurosciences, CHUV, Lausanne, Switzerland.

Funding information and disclosures are provided at the end of the article. Go to Neurology.org/nn for full disclosure forms. The Article Processing Charge was paid by the authors.

This is an open access article distributed under the terms of the Creative Commons Attribution-NonCommercial-NoDerivatives License 4.0 (CC BY-NC-ND), which permits downloading and sharing the work provided it is properly cited. The work cannot be changed in any way or used commercially. 
Table 1 Clinical data of study patients with multiple sclerosis

\begin{tabular}{|c|c|c|c|c|c|c|c|c|}
\hline & $\begin{array}{l}\text { Age at } \\
\text { study } \\
\text { entry, y }\end{array}$ & Sex & $\begin{array}{l}\text { Disease } \\
\text { duration, y }\end{array}$ & $\begin{array}{l}\text { EDSS } \\
\text { score }\end{array}$ & $\begin{array}{l}\text { Total no. relapses } \\
\text { before treatment } \\
\text { onset }\end{array}$ & Previous treatment & $\begin{array}{l}\text { No. patients } \\
\text { reaching time } \\
\text { point }\end{array}$ & $\begin{array}{l}\text { VZV serology index } \\
\text { before treatment } \\
\text { introduction }\end{array}$ \\
\hline $\begin{array}{l}\text { FTY cohort } \\
(n=29)\end{array}$ & $40 / 14.5$ & $21 \mathrm{~F} / 8 \mathrm{M}$ & $9 / 10.5$ & $1.5 / 0.5$ & $3 / 4$ & $\begin{array}{l}15 \text { IFN- } \beta ; 4 \text { GA; } 1 \text { NTZ; } \\
2 \text { cladribine (phase III trial); } \\
7 \text { without }\end{array}$ & $\begin{array}{l}\text { T6: 29; T12: 29; } \\
\text { T24: } 26\end{array}$ & $2.38 / 0.99$ \\
\hline $\begin{array}{l}\text { NTZ cohort } \\
(n=11)\end{array}$ & $38 / 12$ & $10 \mathrm{~F} / 1 \mathrm{M}$ & $6 / 10.5$ & $3 / 2.75$ & $6 / 4.5$ & 7 IFN- $\beta$; 3 GA; 1 mitoxantrone & $\begin{array}{l}\text { T6: } 6 ; \text { T12: 11; } \\
\text { T24: } 9\end{array}$ & NA \\
\hline $\begin{array}{l}\text { Other treatment } \\
\text { cohort }(n=11)\end{array}$ & $37.5 / 13$ & $9 \mathrm{~F} / 2 \mathrm{M}$ & $1.5 / 11$ & $1.5 / 1$ & $2 / 2.5$ & 2 IFN- $\beta ; 1$ GA; 8 without & $\begin{array}{l}\text { T6: 11; T12: 5; } \\
\text { T24: } 0\end{array}$ & NA \\
\hline
\end{tabular}

Abbreviations: EDSS $=$ Expanded Disability Status Scale; FTY $=$ fingolimod; GA $=$ glatiramer acetate; IFN $-\beta=$ interferon $-\beta$; NA $=$ not available; NTZ = natalizumab.

Data represent median/interquartile range unless otherwise specified.

the increased occurrence of herpes zoster $(\mathrm{HZ})$ in these patients may be related to the VZVspecific cellular immune response.

In an attempt to answer these questions, we studied longitudinally the viral-specific cellular immune response against VZV, influenza virus (FLU), and JC virus (JCV) of patients with MS on FTY and on other disease-modifying treatments (DMTs) and in 2 FTY-treated patients with MS who presented an HZ.

METHODS Patients We enrolled 53 patients with relapsingremitting MS (table 1) who were treated with (1) FTY $(\mathrm{n}=31)$, including 2 patients who developed VZV infection while receiving FTY (table 2); (2) natalizumab (NTZ) ( $\mathrm{n}=11)$; and (3) other DMTs (IFN- $\beta[\mathrm{n}=8]$, glatiramer acetate $[\mathrm{n}=2]$, teriflunomide $[n=1])$. None of them was ever vaccinated against VZV, and all of the FTY-treated patients with MS exhibited anti-VZV antibodies before treatment initiation (table 1). The diagnosis of MS was made using the revised McDonald criteria. Blood samples were drawn just before the first DMT administration (T0) and then at 6, 12, and 24 months (T6, T12, and T24, respectively) into treatment or until interruption of the treatment. Peripheral blood mononuclear cells (PBMCs) were isolated and frozen as previously described in detail.

Standard protocol approvals, registrations, and patient consents. This study was accepted by our institution's review board (protocol 172/13) and all participants gave their written informed consent before study initiation.

Enzyme-linked immunospot assay. To detect interferon- $\gamma$ secreting activated T cells specific to VZV, JCV, or FLU, we used an enzyme-linked immunospot (ELISPOT) assay as described previously. ${ }^{9}$ Conditions used were as follows: medium only (negative control); phytohemagglutinin lectin (positive control, $5 \mu \mathrm{g} / \mathrm{mL}$, used as a saturating condition); JCV VP1 pools of sixty-nine 15 -mer peptides, overlapping by 10 amino acids, encompassing the whole VP1 protein, able to elicit a $\mathrm{CD}^{+}$as well as a $\mathrm{CD}^{+} \mathrm{T}$ cell response ${ }^{9}(10 \mu \mathrm{g} / \mathrm{mL})$; VZV peptide pool of sixty-seven 15 mers, overlapping by 11 amino acids, and covering the whole sequence of the immunodominant IE $63^{10-12}$ (VZV pool, JPT peptides, $5 \mu \mathrm{g} / \mathrm{mL}$ ), thus able to elicit $\mathrm{CD}^{+}{ }^{+}$as well as $\mathrm{CD}^{+} \mathrm{T}$ cell response; FLU $\mathrm{CD}^{+}$-restricted 9-mer peptide epitopes ${ }^{13}$ (FLU pool, $1 \mu \mathrm{g} / \mathrm{mL}$ ), as well as VZV and FLU viral lysates (TebuBio, ABI Inc., $1 \mu \mathrm{g} / \mathrm{mL}$ ). Spot counts and mean responses were generated as previously described. ${ }^{9}$ Briefly, all conditions were performed in triplicate and a mean of the results was calculated for each condition. Responses were initially expressed as net spot-forming cells (SFCs) per $10^{6}$ PBMCs. The assay was considered valid if the SFCs, in the absence of peptide (i.e., negative control), were fewer than 40 per $10^{6}$ cells. Validated background values were subtracted from the peptide-stimulated data before analysis. Of note, to take into account the lymphopenic effect of FTY, all SFCs were normalized to $10^{6} \mathrm{CD}^{+} \mathrm{T}$ cells, whose frequency was determined by flow cytometry as described previously. ${ }^{13}$

Statistical analysis. The effect of the group or of treatment duration was assessed in a Kruskal-Wallis analysis of variance. The $p$ values obtained from these analyses of variance are henceforth referred to as $p_{\mathrm{KW}}$. If the effect of the treatment duration reached significance, the differences between immune responses measured at $\mathrm{T} 0$ and various subsequent time points were analyzed with the nonparametric paired Wilcoxon ranked test. A Bonferroni correction was performed to take into account the comparisons performed at multiple time points (T0 vs T6, T0 vs T12, T0 vs T24). These stringent statistical tests were performed to ensure the robustness of any differences found. However, considering the relatively low number

Table 2 Clinical data on the 2 patients with multiple sclerosis who underwent an $\mathrm{HZ}$ while receiving FTY treatment

\begin{tabular}{|c|c|c|c|c|c|c|c|c|c|c|}
\hline & $\begin{array}{l}\text { Age at study } \\
\text { entry, } y\end{array}$ & Sex & $\begin{array}{l}\text { Disease } \\
\text { duration, y }\end{array}$ & $\begin{array}{l}\text { EDSS } \\
\text { score }\end{array}$ & $\begin{array}{l}\text { Total no. relapses } \\
\text { before starting } \\
\text { treatment }\end{array}$ & $\begin{array}{l}\text { Previous } \\
\text { treatment }\end{array}$ & $\begin{array}{l}\text { Zoster onset } \\
\text { (mo after } \\
\text { starting FTY) }\end{array}$ & $\begin{array}{l}\text { Interval zoster } \\
\text { onset/blood } \\
\text { draw, d }\end{array}$ & $\begin{array}{l}\text { VZV serology } \\
\text { index before } \\
\text { starting FTY }\end{array}$ & $\begin{array}{l}\text { Involved } \\
\text { dermatoma }\end{array}$ \\
\hline HZ 1 & 30 & $\mathrm{~F}$ & 0.5 & 2.0 & 2 & None $^{a}$ & 5 & +18 & 1.82 & C4 \\
\hline
\end{tabular}

Abbreviations: EDSS = Expanded Disability Status Scale; FTY = fingolimod; HZ = herpes zoster; IFN- $\beta=$ interferon- $\beta$; VZV = varicella-zoster virus. ${ }^{a} \mathrm{HZ} 1$ received methylprednisolone 5 weeks before blood draw at TO. 


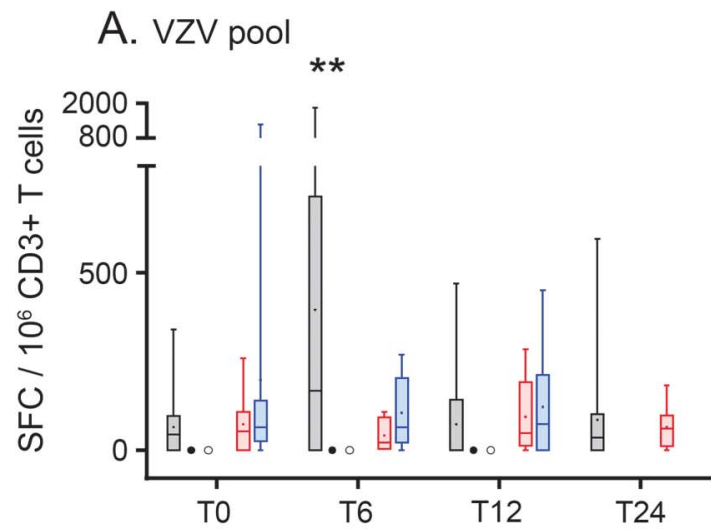

B. VZV lysate
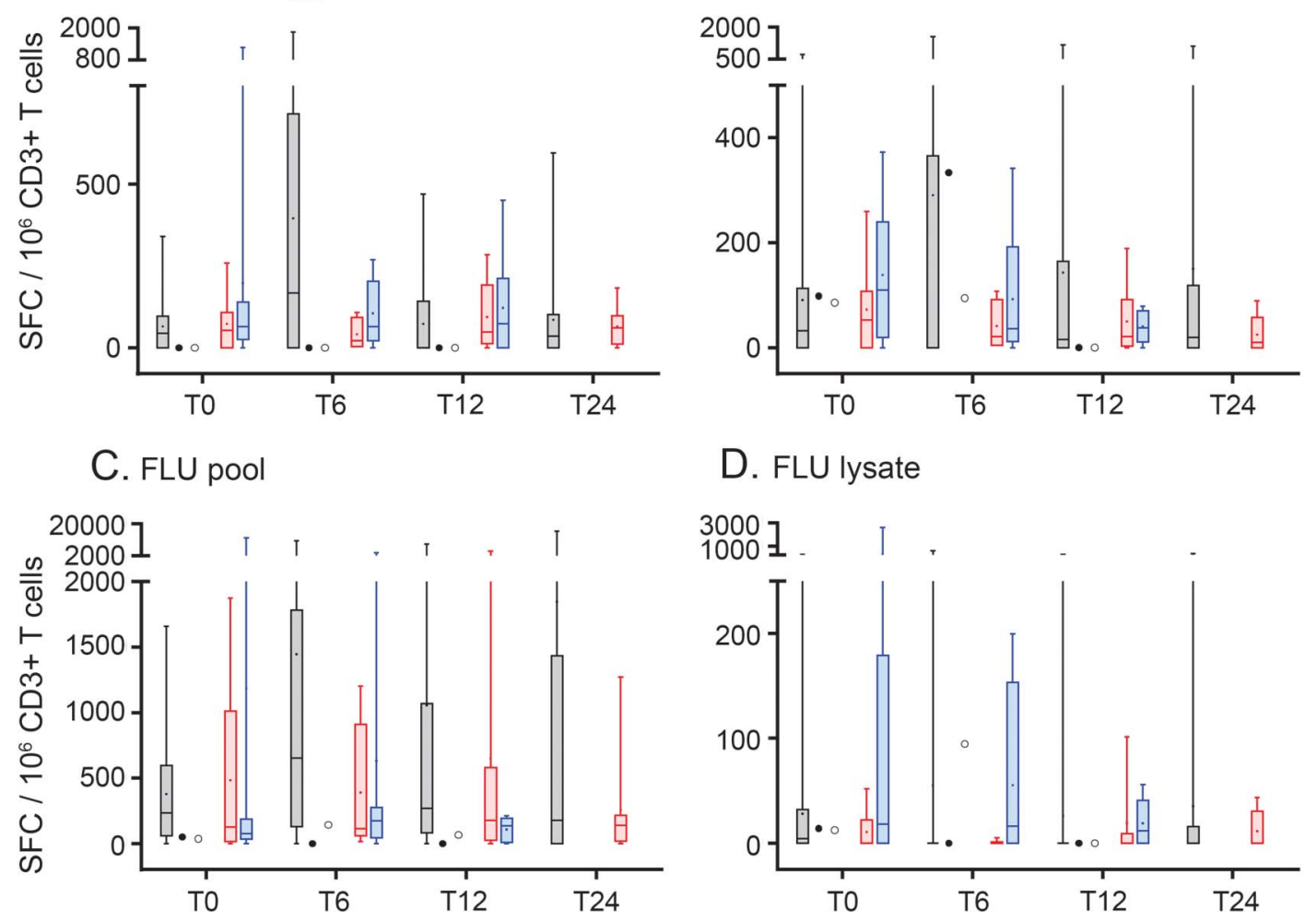

\section{E. JCV pool}
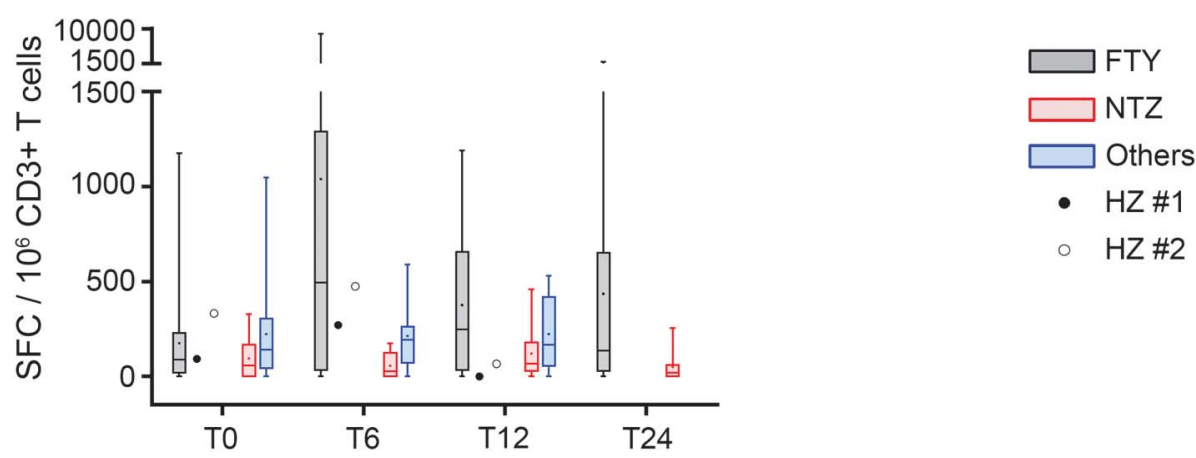

Interferon- $\gamma$-mediated cellular immune responses against pool of peptides encompassing the whole VZV/IE63 protein (A), VZV viral lysate (B), pool of selected peptides of FLU (C), FLU viral lysate (D), and pool of peptides encompassing the whole JCV VP-1 protein (E) were tested using enzyme-linked immunospot assay. Data were obtained before treatment initiation (TO), and after 6 (T6), 12 (T12), and 24 months (T24) of treatment. Data of FTY-treated patients with multiple sclerosis appear in black in the graphs, NTZ-treated patients in red, and patients under other DMTs in blue. Responses reached by the 2 patients who underwent an $\mathrm{HZ}$ during FTY treatment are represented as dots on the graphs. Box and whisker plots show median, 25th and 75th percentiles, and range. The mean is represented as a dot in the box. The effect of the treatment duration for each treated group was assessed in a Kruskal-Wallis test. If significant, TO was then compared to subsequent time points using pairwise unparametric Wilcoxon tests corrected for Bonferroni multiple comparisons. The asterisks represent differences for the effect of time for a given treatment. In all of these experiments, only data of FTY-treated patients at T6 and for IE63 reached significance; **P $<0.01$. FLU = influenza virus; FLU pool = FLU pool of CD8 ${ }^{+}$restricted peptides; FTY = fingolimod; HZ = herpes zoster; JCV = JC virus; JCV pool = JCV VP-1 protein; NTZ = natalizumab; others = other disease-modifying treatments (DMTs); SFC $=$ spot-forming cell; VZV = varicella-zoster virus; VZV pool $=$ VZV IE63 protein.

of study patients, we cannot rule out that milder differences have gone unnoticed. Correlations between VZV serology index and SFC counts obtained after VZV/IE63 or VZV lysate stimulation were analyzed using the Spearman test. Probability values $<0.05$ were considered significant. All statistical analyses were performed with GraphPad Prism version 6.04 (GraphPad Software, La Jolla, CA).

RESULTS Before treatment onset, the 3 groups of patients showed comparable $\mathrm{CD}^{+} \mathrm{T}$ lymphocyte 
frequencies among thawed PBMCs (median/interquartile range $=26.8 \% / 20.3 ; p_{\mathrm{KW}}=0.477$; figure e-1 at Neurology.org/nn). No significant difference was found between MS patient categories for age, disease duration, and sex. However, significantly fewer patients were treatment-naive at the start of NTZ or FTY treatment than for IFN- $\beta$ or glatiramer acetate treatment, in accordance with clinical practice. As expected, FTY induced a marked lymphopenia at all time points tested, reducing the median frequency of $\mathrm{CD}^{+} \mathrm{T}$ cells by $83 \%$ to $89 \%$, of $\mathrm{CD}^{+} \mathrm{T}$ cells by $96 \%$, and of $\mathrm{CD}^{+}$ T cells by $77 \%$ to $83 \%$, as compared to T0. Neither NTZ nor any other DMT statistically affected the $\mathrm{CD}^{+} \mathrm{T}$ cell population (figure e-1).

To assess whether FTY interferes with antiviral immune responses, IFN- $\gamma$ secretion by PBMCs was measured by ELISPOT upon VZV, FLU, and JCV stimulations. Baseline responses were similar in all groups tested whatever the antigen used (figure 1, T0). Of main interest, as compared to T0, we detected a 3.8-fold increase of the VZV/IE63-specific cellular immune response in FTY-treated patients at T6 (corrected Wilcoxon ranked test, $p=0.0096$ ), which returned to normal at subsequent time points (figure $1 \mathrm{~A}, p_{\mathrm{KW}}=0.0372$ ). By contrast, FTY-treated patients with MS did not present any increased cellular immune response against VZV lysate $\left(p_{\mathrm{KW}}=\right.$ $0.9654)$, JCV pool $\left(p_{\mathrm{KW}}=0.1065\right)$, FLU pool $\left(p_{\mathrm{KW}}=0.2299\right)$, or FLU lysate $\left(p_{\mathrm{KW}}=0.1452\right)$ at any time point tested (figure $1, \mathrm{~B}-\mathrm{E}$ ). In addition, we did not observe any difference in the viral-specific cellular immune responses of patients on NTZ or other DMTs. Of note, the 2 patients who had HZ after 6 months of FTY treatment did not develop any VZV/IE63-specific cellular immune response at the time of $\mathrm{HZ}$ onset (figure $1 \mathrm{~A}$ ). Somewhat contrasting, at the time of their HZ onset, the VZV lysate-specific cellular immune response seemed to be normal (figure $1 \mathrm{~B}, \mathrm{~T} 6)$. It is of interest that we found a significant correlation at T0 between the VZV antibody index and the VZV/IE63-specific but not the VZV lysate-specific $\mathrm{T}$ cell response, pointing to the central immunogenic role of IE63 (figure e-2).

DISCUSSION FTY-treated patients with MS have a 1.6-fold increased risk of developing $\mathrm{HZ}$, as compared to other patients with MS. The risk of $\mathrm{HZ}$ is maximal at 6 months into treatment, without any peculiar increase afterward. ${ }^{6}$ Adding to this observation, serious or even fatal cases of disseminated VZV infection were reported in FTYtreated patients. ${ }^{3,6,14,15}$ However, the reason for such a VZV reactivation is still poorly understood.

Herein, we show that, ex vivo, the cellular immune response specific to VZV, JCV, and FLU by ELISPOT assay is maintained in FTY-treated patients as compared to control patients with MS. However, there is a notable exception for VZV/ IE63-specific $T$ cell response, which is clearly increased after 6 months into FTY treatment as compared to patients with MS who have other DMTs. Yet, this 6-month time point precisely coincides with the reported peak of $\mathrm{HZ}$ incidence. ${ }^{6}$

Of note, the 2 FTY-treated patients who developed HZ had an undetectable VZV/IE63-specific cellular immune response at the time of the onset of their HZ (T6). These results suggest that the VZV/IE63-specific T cell response may be key in preventing the onset of HZ in FTY-treated patients. A slightly reduced antiviral $\mathrm{T}$ cell response has been previously found in patients treated with FTY whereby $11 \%$ of them had a subclinical reactivation of VZV in the saliva. However, in contrast to our methods, these authors did not normalize their data. Thus, the question remains open whether the decreased VZV-specific T cell response may simply reflect the lymphopenia associated with VZV. ${ }^{8}$ Clearly supporting our data, others have found that a deficiency in IE63-specific $T$ cell response was associated with a subclinical VZV reactivation in patients with malignancies, whereas the immune response directed against the VZV-glycoprotein $\mathrm{gE}$ was maintained in the same group of patients. ${ }^{16}$

In conclusion, in this longitudinal observational study with FTY-treated patients and control patients with MS, we show that the overall viral-specific cellular immune response is preserved in FTY-treated patients with $\mathrm{MS}$ when normalized to the $\mathrm{CD}^{+} \mathrm{T}$ cell count. Our data further suggest that a VZV reactivation occurs at 6 months under FTY and that, at this time, the VZV/IE63-specific cellular immune response seems to be crucial in preventing the onset of $\mathrm{HZ}$ under FTY treatment. To further establish that VZV reactivation takes place at 6 months into FTY treatment, it may be of interest for future studies to encompass determination of VZV DNA and of VZVspecific antibodies in the blood, and possibly also in the CSF, at different time points. Such studies will also tell whether the determination of the VZV/IE63specific cellular immune response may serve to identify patients at risk of $\mathrm{HZ}$. Until then, and based on our data, which show a correlation between the VZVI IE63-specific cellular immune response and the VZV antibody index, we suggest that it is important to vaccinate future FTY-treated patients with MS who have a low VZV antibody index.

\section{AUTHOR CONTRIBUTIONS}

A.M. designed the research, performed the experiments, analyzed the data, and wrote the manuscript. G. Perriard discussed the results and revised the manuscript. M.C. performed the experiments and analyzed the data. F.V. performed the experiments and analyzed the data. 
G. Perrotta provided clinical data and discussed the results. M.S. enrolled patients, provided clinical data, and revised the manuscript. R.D.P. designed the research, wrote the manuscript, and supervised the study.

\section{ACKNOWLEDGMENT}

The authors thank G. Le Goff for help in enrolling patients and obtaining blood samples and Nils Jonkmans for thorough reading of the manuscript.

\section{STUDY FUNDING}

This work was supported by grants from an investigator-initiated tria (Novartis), the Swiss National Foundation (320030_159997), and the Swiss MS Society.

\section{DISCLOSURE}

A. Mathias, G. Perriard, M. Canales, F. Vuilleumier, and G. Perrotta report no disclosures. M. Schluep served on the scientific advisory board for and received travel funding and/or speaker honoraria from Biogen, Genzyme, Merck Serono, Novartis, and Sanofi-Aventis, consulted for Biogen, Merck Serono, Novartis, Genzyme, and Sanofi-Aventis, and received research support from Merck Serono, Novartis, and Biogen. R.A. Du Pasquier served on the scientific advisory board for Biogen and Genzyme, received travel funding and/or speaker honoraria from Sanofi and Genzyme, is on the editorial board for Journal of Neurovirology, and received research support from the Swiss Society for Multiple Sclerosis and Novartis. Go to Neurology.org/nn for full disclosure forms.

Received September 22, 2015. Accepted in final form December 27, 2015.

\section{REFERENCES}

1. Mehling M, Brinkmann V, Antel J, et al. FTY720 therapy exerts differential effects on $\mathrm{T}$ cell subsets in multiple sclerosis. Neurology 2008;71:1261-1267.

2. Huang D. Disseminated cryptococcosis in a patient with multiple sclerosis treated with fingolimod. Neurology 2015;85:1001-1003.

3. Cohen JA, Barkhof F, Comi G, et al. Oral fingolimod or intramuscular interferon for relapsing multiple sclerosis. N Engl J Med 2010;362:402-415.

4. Pfender N, Jelcic I, Linnebank M, et al. Reactivation of herpesvirus under fingolimod: a case of severe herpes simplex encephalitis. Neurology 2015;84:2377-2378.

5. US Food and Drug Administration. Gilenya (fingolimod) drug safety communication: investigating rare brain infection. 2013. Available at http://www.fda.gov/Safety/MedWatch/
SafetyInformation/SafetyAlertsforHumanMedicalProducts/ ucm366751.htm. Accessed September 22, 2015.

6. Arvin AM, Wolinsky JS, Kappos L, et al. Varicella-zoster virus infections in patients treated with fingolimod: risk assessment and consensus recommendations for management. JAMA Neurol 2015;72:31-39.

7. Calabresi PA, Radue EW, Goodin D, et al. Safety and efficacy of fingolimod in patients with relapsing-remitting multiple sclerosis (FREEDOMS II): a double-blind, randomised, placebo-controlled, phase 3 trial. Lancet Neurol 2014;13:545-556.

8. Ricklin ME, Lorscheider J, Waschbisch A, et al. T-cell response against varicella-zoster virus in fingolimodtreated MS patients. Neurology 2013;81:174-181.

9. Jilek $\mathrm{S}$, Jaquiery E, Hirsch $\mathrm{HH}$, et al. Immune responses to JC virus in patients with multiple sclerosis treated with natalizumab: a cross-sectional and longitudinal study. Lancet Neurol 2010;9:264-272.

10. Sadzot-Delvaux C, Arvin AM, Rentier B. Varicella-zoster virus IE63, a virion component expressed during latency and acute infection, elicits humoral and cellular immunity. J Infect Dis 1998;178(suppl 1):S43-S47.

11. Jones L, Black AP, Malavige GN, et al. Phenotypic analysis of human CD4 $+\mathrm{T}$ cells specific for immediate-early 63 protein of varicella-zoster virus. Eur J Immunol 2007; 37:3393-3403.

12. Vukmanovic-Stejic M, Sandhu D, Sobande TO, et al. Varicella zoster-specific CD4+Foxp3+ T cells accumulate after cutaneous antigen challenge in humans. J Immunol 2013;190:977-986.

13. Antoniol C, Jilek S, Schluep M, et al. Impairment of JCVspecific T-cell response by corticotherapy: effect on PMLIRIS management? Neurology 2012;79:2258-2264.

14. Ratchford JN, Costello K, Reich DS, et al. Varicella-zoster virus encephalitis and vasculopathy in a patient treated with fingolimod. Neurology 2012;79:2002-2004.

15. Issa NP, Hentati A. VZV encephalitis that developed in an immunized patient during fingolimod therapy. Neurology 2015;84:99-100.

16. Malavige GN, Rohanachandra LT, Jones L, et al. IE63specific T-cell responses associate with control of subclinical varicella zoster virus reactivation in individuals with malignancies. Br J Cancer 2010;102:727-730. 


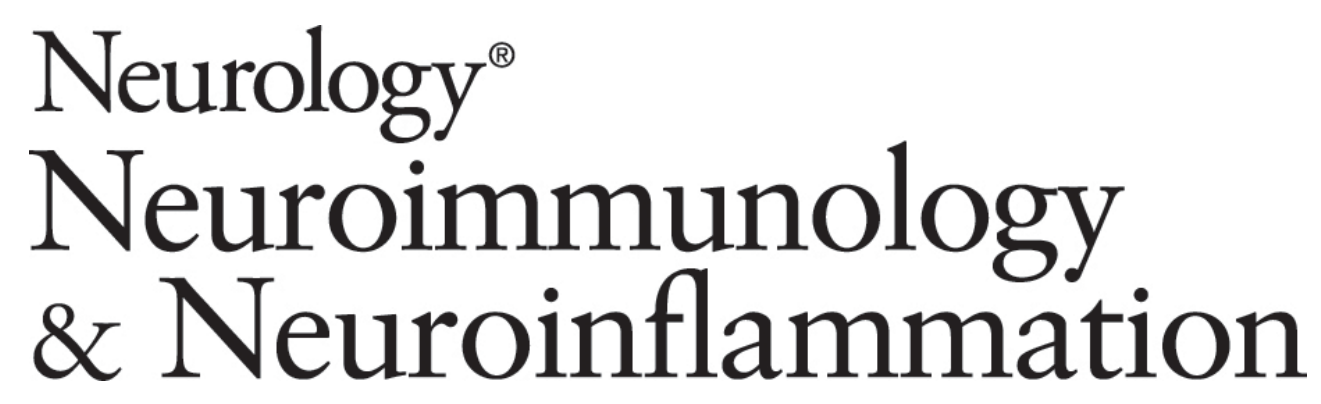

The VZV/IE63-specific $T$ cell response prevents herpes zoster in fingolimod-treated patients

Amandine Mathias, Guillaume Perriard, Mathieu Canales, et al.

Neurol Neuroimmunol Neuroinflamm 2016;3;

DOI 10.1212/NXI.0000000000000209

This information is current as of February 10, 2016

Neurol Neuroimmunol Neuroinflamm is an official journal of the American Academy of Neurology.

Published since April 2014, it is an open-access, online-only, continuous publication journal. Copyright $\odot$ 2016 American Academy of Neurology. All rights reserved. Online ISSN: 2332-7812.

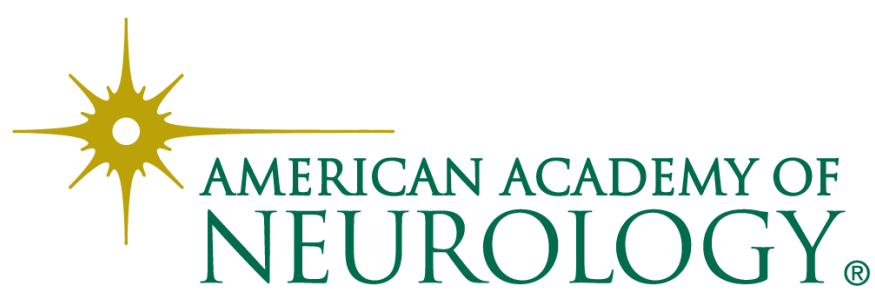




\section{Updated Information \&} Services

\section{Supplementary Material}

\section{References}

Citations

Subspecialty Collections

Permissions \& Licensing

\section{Reprints}

including high resolution figures, can be found at: http://nn.neurology.org/content/3/2/e209.full.html

Supplementary material can be found at: http://nn.neurology.org/content/suppl/2016/02/11/3.2.e209.DC1

This article cites 15 articles, 1 of which you can access for free at: http://nn.neurology.org/content/3/2/e209.full.html\#\#ref-list-1

This article has been cited by 1 HighWire-hosted articles: http://nn.neurology.org/content/3/2/e209.full.html\#\#otherarticles

This article, along with others on similar topics, appears in the following collection(s):

\section{All Immunology}

http://nn.neurology.org//cgi/collection/all_immunology

\section{All Infections}

http://nn.neurology.org//cgi/collection/all_infections

Multiple sclerosis

http://nn.neurology.org//cgi/collection/multiple_sclerosis

Patient safety

http://nn.neurology.org//cgi/collection/patient_safety

Information about reproducing this article in parts (figures,tables) or in its entirety can be found online at:

http://nn.neurology.org/misc/about.xhtml\#permissions

Information about ordering reprints can be found online: http://nn.neurology.org/misc/addir.xhtml\#reprintsus

Neurol Neuroimmunol Neuroinflamm is an official journal of the American Academy of Neurology.

Published since April 2014, it is an open-access, online-only, continuous publication journal. Copyright $\odot$ 2016 American Academy of Neurology. All rights reserved. Online ISSN: 2332-7812.

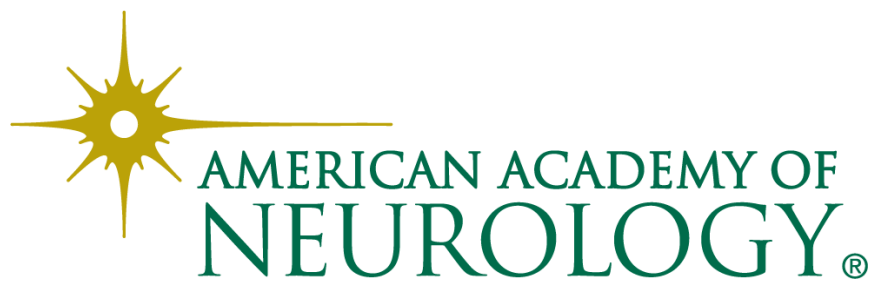

